\title{
The Crisis and Construction of Identity in Joyce Carol Oates's Novel The Tattooed Girl
}

\author{
Wang Jing \\ School of Foreign Languages, Soochow University, Jiangsu, China
}

Copyright $\bigcirc 2018$ by authors, all rights reserved. Authors agree that this article remains permanently open access under the terms of the Creative Commons Attribution License 4.0 International License

\begin{abstract}
In The Tattooed Girl, Joyce Carol Oates focuses mainly on the issue of identity, portraying the individual identity crisis and dramatizing racial and class conflicts between the privileged Jews and "white trash", a marginalized white group. This paper will study the issue of crisis and construction of identity in this novel from the following aspects: how the characters struggle with the identity crisis, in what ways they attempt to invent their own identity respectively and whether their attempts succeed. By analyzing the tragic ending of the novel, this thesis will discuss how the recurring theme in Oates's works that whether it is possible to escape one's destiny, manifests in this particular novel.
\end{abstract}

Keywords Identity, Crisis, Construction, The Tattooed Girl, Joyce Carol Oates

\section{Introduction}

Joyce Carol Oates is an acclaimed American writer best known for her prolificacy and acute social observation. She is "a writer who embarks on ambitious projects; her imagination is protean; her energies and curiosity seemingly boundless; and throughout all her writing, the reader detects her sharp intelligence, spirit of inquiry, and her zeal to tell a story," observed by Carol Simpson Stern, [1] a contemporary American novelist and essayist.

To explore American society in different historical context has consistently been one of Oates's major concerns in her literary writing. She considers herself a chronicler of the American experience, and has established a reputation for unrelentingly revealing the social issues and the dark side of the American society in different periods. She exhibits "an uncanny knack for understanding middle America, suburbia, and the temper of the times," to quote Stern.[1]

Since the beginning of the 1990s, Oates manifests a growing interest in the issues of identity and ethnicity through her fiction. Her novels I Lock My Door Upon
Myself (1990), Because It Is Bitter, And Because It Is My Heart (1990), I'll Take You There (2002) all touch upon identities and racial relations, exposing the harsh reality of racial discrimination and prejudice in American society and exploring ways of identity construction. In The Tattooed Girl (2003), Oates takes up this theme again and focuses on Joshua Seigl, an elite Jew, and Dmitri as well as Alma from the deprived American lower class, dramatizing racial and class conflicts between the privileged Jews and "white trash", a marginalized white group.

Some researchers have already noticed Oates's preoccupation with the issue of identity in The Tattooed Girl and discussed it from different perspectives. Lorna Hardwick and James I. Porter (2011) focused on Oates's representation of America's national identity crisis after the terrorist attacks of 11 September 2001 by looking to Virgil. They pointed out that Oates's invocation of Virgil at a time of national crisis was because of Virgil's strong association with the reassertion of national identity after conflict.[2] Wang Xiaodan (2013) examined Oates's interpretation of social identity by probing into characters from different social classes. It was concluded that the lower class with a subordinate social identity were doomed to fail in their futile attempts to break the social identity boundary.[3] Enlightening as these papers are, there is, however, no other significant research done on this novel, partly because of Oates's extraordinary productivity, which turns researchers to her other works.

This thesis studies The Tattooed Girl from a new perspective, aiming to reveal how the three main characters in the novel struggle with the identity crisis and attempt to reconstruct identity through their own effort. By analyzing the tragic ending of the novel, this thesis will discuss how the recurring theme in Oates's works that whether it is possible to escape one's destiny, manifests in this particular novel.

\section{Jewish Identity and Literature}

The Tattooed Girl focuses on Joshua, a prestigious but 
reclusive writer, and depicts how he was trapped in identity crisis and how he tried to construct a new identity through translation and writing.

Joshua was confronted with identity crisis in many aspects. As an American, he believed that he was "European by temperament"; [4] as a novelist; he assumed that he was a philosopher by nature. However, his utmost confusion came from his Jewish identity. Stuart Hall once defined a "sociological subject", whereby identity is formed in the modern world "in the interaction between self and society".[5] Within this conception of identity, the self is "interactive" rather than purely individual and fully unified. One projects oneself into these cultural identities, at the same time internalizing their meanings and values. According to Hall, the gap between "inside" and "outside", between personal and public worlds, between Self and Other, is thus bridged. In Joshua's case, however, there was a considerable discrepancy between who he was in others' mind and who Joshua believed he was.

On one hand, Joshua was identified as Jewish by everyone else. And there were a couple of reasons accounting for that identification. He was from a well-to-do Jewish family and was named "Joshua Moses Seigl", a name full of Jewish culture and religious significance. Besides, Joshua was acclaimed for his best-selling book The Shadows, a fictionalized memoir of the Holocaust survivors. Hence, Joshua was widely believed as a Jew. Knowing this identity imposed on him by others, Joshua once admitted that, "Of course, the Nazi would have classified me as Jewish. I'd have had to wear a yellow star."'4] Joshua's words reminded readers of what Sartre once said about being a Jew. Sartre insisted that, the Jew did exist. He famously asserted that the Jew was not someone who had a Jewish body or soul or religion or culture: "The Jew is one whom other men consider a Jew".[6] Therefore, it is being considered a Jew that constitutes the Jew's "situation". In this sense, Joshua was Jewish in others' preconceived notion.

On the other hand, however, Joshua felt alienated from Jewish identity or he found it difficult to define himself as a real Jew. Strictly speaking, Joshua was not Jewish by blood as his father was Jewish while his mother was not. According to Jewish custom, one must have a Jewish mother in order to be Jewish by birth. Meanwhile, he did not choose to be Jewish by conversion since he was baptized in a Christian church. He tried to ignore the influence of his Jewish past, not wanting to be identified as Jewish. He once declared openly that, "I am not my ancestors...I am not my father, I am scarcely myself."[4]

Joshua's denial of his Jewish identity was in stark contrast with the strong belief in Jewishness held by his sister Jet and Essler, a young Jewish student who applied for the job of being Joshua's assistant. Both Jet and Essler took the Jewish history and tradition as their heritage and considered it their duty to bring the story of the Holocaust survivors into the new century. For Jet, she was baptized as "Mary Beth Seigl", which she considered very bland and later adopted a Hebrew name Jetimah Steadman-Seigl. She urged Joshua to write a sequel to The Shadows, believing that in doing so, they could bring alive "the memory of their father and his people".[4] To Jet, Jewishness was a unique heritage passed down from their father and was a defining quality of her.

In contrast with Jet, Joshua showed "a waning sense of identity as a distinct people that is manifest everywhere in Jewish America".[7] Instead of writing a sequel to The Shadows, Joshua turned to translating Virgil's poems. Obviously, Jewishness weighed very lightly on him and in doing so, he tried to escape from his Jewish identity. To Jet, Joshua didn't shoulder his responsibility to the whole family and also the whole Jewish people. She rebuked him by saying,

"You're deeply into denial, Joshua. Your career is in tatters and you don't seem to care. This 'autoimmune' condition: it's your own self turning against you. But in destroying yourself you're destroying others, too. The memory of our family. Our heritage."[4]

As numerous American Jews, Joshua sought to blend in with American norms and tried to escape from his Jewishness. His escape reflected an identity crisis, not only of an individual but also of the Jewish people. The American Jews, as a people, "have never been in greater danger of disappearing through assimilation, intermarriage and low birthrate", as Alan Dershowitz put it.[8]

However, as Jet predicted, Joshua could not get out from under his destiny. Jewishness was like what the title of his book suggested, a shadow, which could not be separated from him. Considered widely as a Jew, he suffered from feelings of estrangement and isolation from the surrounding society as he tried to find his place as a writer and a public figure in the American society. One of the motifs of his book The Shadows had been the yearning of displaced, homeless people for home. He didn't realize it that he took as his own the voice of others yearning for home. To him, being Jewish was a heavy burden. However, it was also a support without which he could not live. When he suffered from a nerve disease and found it difficult to walk, he didn't buy a walking stick. Instead, he searched his house and found "a specimen, very likely a cane used by his Steadman grandfather".[4] The antique cane was a metaphor of him carrying his past with him, both as a burden and a support.

Being trapped in identity crisis, Joshua turned to literature in an attempt to construct a new identity. For him, literature is a defining part in his identity, especially professional identity. In other areas, others, especially Jet, tried to affect or define his identity. Literature, however, is something he could be in charge of. First, he turned to translating Virgil's poem Aeneid since "Virgil is associated so strongly with the reassertion of national identity after 
conflict".[2] Therefore, he contents himself with working on his translation, hoping to find ways of constructing a new identity through Virgil. By retreating into the world of the Aeneid, Joshua attempted to find a solution to his identity crisis. However, he failed to realize that, as an author, he should write his own stories about himself rather than be a character in others' narratives. Patricia Waugh once put it, "Composing a novel is no different from composing or constructing one's own 'reality".,[9] Therefore, by writing, writers can create or construct identities through their deployment of discoursal resources in their own written texts. In this sense, Jet was right in claiming that writing instead of translation was in effect inventing one's identity. Joshua's engagement in Virgil's translation could not provide any answer to his quest for a new identity, which would be doomed to failure.

\section{White Trash, Passing and Violence}

In The Tattooed Girl, Oates depicts not only the crisis of racial identity confronted by Joshua, but also the social identity crisis of the whites from the lower class. Dmitri, a well-mannered waiter by day and a drug addicted pimp by night, was in consistent anxiety about whiteness and therefore ran into a similar situation as Joshua. He resorted to, however, passing and violence to reassert his authority and construct identity.

As a waiter, Dmitri was in a subordinate position in the American social hierarchy. He was a nobody, whose last name was Meatte, which had "no romance or mystery".[4] As is well known to all, surnames serve as a symbol of identity and social status. In contrast to Joshua's family name which represented wealth and fame, Dmitri's anonymous last name signified his inferior social identity as well as subordinate position. Dmitri dropped out from college and his life was completely messed up by drugs. In a sense, Dmitri was the typical "white trash".

Like "trailer trash", "rednecks", "lubbers", "clay-eaters" or "crackers", "white trash" is a derogatory term to describe the American underclass. Anthony Harkins writes that the label refers to white people who deal with "economic, genetic, and cultural impoverishment".[10] The earliest use of the term dates back to the early $19^{\text {th }}$ century. It helps solidify a sense of cultural and intellectual superiority for the middle and upper classes. Besides, there is also a tinge of racial discrimination in the phrase. As John Waters points out, "white trash" is not just a classist slur-it's also a racial epithet that marks out certain whites as a breed apart, a dysgenic race unto themselves.[11] Generally speaking, white trash have been considered as a diseased breed and "the degenerate spawn of a notorious race".[12] They were once classified as a race that passed on undesirable traits, including being incestuous and sexually promiscuous, violent, alcoholic, lazy and stupid.
Daniel Hundley once claimed that, "Everywhere they are just alike, possess pretty much the same characteristics, the same vernacular, the same boorishness, and the same habits...everywhere, Poor White Trash."[13] And George Weston also wrote in his book The Poor Whites of the South (1856) that, they were "sinking deeper and more hopelessly into barbarism with every succeeding generation".[14] From 1880 to 1920, an organization called the Eugenics Records Office carried out 15 studies, trying to prove that rural poor whites were "genetic defectives".[15] Evidently, the lower classes are considered as incurable and irreparable "breeds", and have been compared to a racial minority.

Dmitri belonged to "white trash". White as he was, he was considered as "a separate race in, but not of, white America".[12] Inevitably, he suffered from whiteness anxiety and was plunged in identity crisis, especially when he was with Joshua, a upper-class Jewish elite. Joshua's wealth and social status reminded Dmitri of his own inferiority and questioned his identity as a white. Therefore, Dmitri hated Joshua; hated serving him, accepting his lavish tips, having to be grateful and having to like him. He even believed that Joshua left generous tips to "show his superiority". [4] To him, Joshua was "the Other" in every way: wealthy and highly educated. As in Stuart Hall's words, "all identity is constructed across difference".[16] Difference is central to one's understanding of identity construction as identity means living through differences. The differences between Dmitri and Joshua compelled Dmitri to realize a cruel fact that he was nothing but white trash, a genetically inferior race and a white "other", "a construction both within and beyond the confines of American 'whiteness"'.[10]

Dmitri craved being out of marginalization and subordinate status and therefore attempted to create a new identity by passing for someone he definitely was not. Passing is "the ability of a person to be regarded as a member of an identity group or category different from their own, which may include racial identity, ethnicity, caste, social class, sexual orientation, gender, religion, age and/or disability status".[17] Elaine K. Ginsberg connects passing with identities, claiming it is "their creation or imposition, their adoption or rejection, their accompanying rewards or penalties".[18] According to her, passing is a way of avoiding the enclosures of a unitary identity. Therefore, by passing, one can invent his or her different identities. And that explained why Dmitri pretended to be polite and friendly when serving Joshua. He tried to eliminate class difference and narrow the gap between him and Joshua by behaving like a gentleman. To some degree, he succeeded in creating a new identity as Joshua was completely fooled and took him as a reliable and amiable man.

Besides, Dmitri asserted his authority through violence. Violence is a recurring theme overshadowing everything in Oates's books. It is not merely a result of frustration caused 
by factors such as unequal political power, but it is also a way of defining one's identity. As Jutta Meuronen observed, "the violence in her (Oates's) works serves many functions from the characters' perspective, as it is both a reaction to surrounding society and the frustration it causes to an individual, as well as a way for said individual to construct their own identity."[19] Samuel Kirubahar also noted that, "her characters fall back on violence when they are confronted with threats to their self-image or with the exposure of their impotence."[20] Violence is, undoubtedly, a means of claiming authority and creating a more powerful identity. By falling back on violence, Dmitri successfully overcame impotence and regained power and superiority. "He laughed, enjoying this...Cunt, he called her, fat cunt, knocked her staggering backward with a clip to the jaw, so hard he hurt his knuckles, one-two slamming her in the fat boobs, he'd knock her fucking teeth out, she tried this shit again. A human punching bag, the Tattooed Girl.'[4] For Dmitri, violence served as a way of self-affirmation and functioned as an agency of constructing a new identity.

Oates's depiction of Dmitri and white trash reveals the dark side of American society and exposes the myth of "American exceptionalism", a belief that the United States is uniquely virtuous and totally different from other nations. America has long been steeped in the myth of classlessness. The absence of class is claimed to be one of American hallmarks. However, by portraying Dmitri and his whiteness crisis, Oates reveals the hypocrisy of American society and the spiritual trauma of people from the lower class. Passing and violence, both as ways of constructing new identities, are therefore inevitable under such circumstances. However, both of these two methods cannot serve as real ways for the lower class to get rid of their identity crisis. Instead of eliminating class differences and stratification, they provide only illusion for them to feel powerful.

\section{Female Body and Anti-Semitism}

Apart from two male protagonists, Oates has also portrayed a female character, Alma, her identity crisis as well as her endeavor to get rid of this crisis through anti-Semitism. Alma, the title character of The Tattooed Girl, is a barely literate young girl who, driven by the anti-Semite hatred, wages a murderously vengeful campaign against her employer. However, her anti-Semitism was merely the outcome of a disturbed identity and a way of self-construction.

As locus of desire, Alma is othered and labeled different both corporally (her tattoos) and mentally (her illiteracy). Alma, a sensuous and physically attractive young woman, was nothing but a beautiful yet mysterious body to two male protagonists in the novel. Her identity was from others' perception of her and was solely an empty body without soul or feelings. With meticulous details, Oates describes Alma's body: "Her full, round face was eerily white and the blemish on her cheek was prominent. And her mouth that cheap luscious red".[4] Her skin, mouth, face were described with such frequency that they overshadowed all other aspects of her and concealed her inner being. To Dmitri, Alma was objectified as flesh and a body which in turn could make money for him.

What were most striking about her, though, were those bizarre tattoos on her right cheek and her body. There was magenta, moth-shaped mark on her right cheek. Apart from that, her forearms and the backs of her hands were also marked and there was a filigree of magenta and dull red on her neck. Her tattoos attracted Joshua as they were reminiscent of the Holocaust victims' prison-camp tattoos. The crude tattoos were like cobwebs sticking to her skin. Like graffiti, or drunken speech. As Eithne Farry observed, Alma's tattoos "are ugly, defacing, like someone scribbling on the wall. They are acts of vandalism on her body. They are not works of art; she didn't elect to have them.'[21] However, these ugly tattoos attracted the attention of Joshua and became an identity of Alma. She was referred to as the tattooed girl, instead of her real name throughout the novel. To Joshua, she was only a blemished body deserving pity.

Apart from being an empty body, Alma was also marginalized in the social ladder. White-skinned as she was, she was considered by others as white trash like Dmitri. She came from an impoverished family in a village called "Akron", quite similar to the Virgilian "Acheron"- - the Underworld. The first day she appeared in The Café, she was penniless and was described by Dmitri as a dog, "a borzoi" and "a beautiful soft fleshy goose you wanted to fatten".[4] White trash as both Dmitri and Alma are, Dmitri occupied a dominant position over Alma. To Dmitri, Alma was just a devalued sex object subjected to violence and sadism. As for Joshua, kind as he was to her, he still considered her as an outsider and the Other. Her otherness was strengthened by her illiteracy. As the assistant to Joshua, Alma had to take care of the scripts of Joshua's translation. In reading these scripts, she regarded them as a weapon of exclusion and felt expelled by the superiority of Joshua's good education. She felt an identity crisis of being a white American and challenged in her whiteness. Richard Dyer once claimed that, the terror of whiteness arises "because of its blankness and emptiness which evokes meaninglessness and pointlessness".[22] Alma's whiteness turned into a terror, exemplifying her ignorance, which in turn caused her identity crisis.

To get rid of this identity crisis, she harbored a virulent anti-Semite hatred toward her employer, Joshua. In describing her anti-Semitism, Oates reveals a disturbing fact in the American society. In America, Jews are but a small portion of the whole population. However, they are a minority that cannot be ignored. If success is to be measured by educational, occupational and political importance, Jews are a people who are extremely successful in all fields of American society. Success does 
not necessarily bring security, however. Even nowadays, American Jews are still confronted with a wide-spread anti-Semitism. On November 25, 1998, the New York Times published an article, proclaiming that "one out of eight Americans has hard-core Anti-Semitic feelings."[23] In Alma's case, Alma was taught to hate Jews when she was young. Her grandfather used to call a Jew "a despised thing" and claimed vaguely that as Judas killed Christ, Jews are "accursed of God and man".[4] Later she was further influenced by Dmitri, believing that the Holocaust might be the biggest hoax of the twentieth century. Her hatred toward Jews was completely based on supposition and perceived truths rather than her personal experience. Joshua once asked Alma that, "Do you personally believe, Alma, that Jews are somehow different from you and your family? Jews are -what? Exotic? Treacherous? Dangerous? Not to be trusted? Likely to swindle you? A separate and distinct race of the human being?" [4] He didn't realize that these were all true in Alma's mind.

Alma seethed inside anti-Semitism in an attempt to construct her identity or whiteness through Joshua's Jewishness. Even though she might be considered white trash and was in the lowest position, she felt in some way a social superiority in comparison to the Jew because at least she was white. According to Sartre, "treating the Jew as an inferior and pernicious being makes it possible for poor people to feel they are part of the elite".[4] It is in opposing themselves to the Jew that these poor whites suddenly become conscious of being proprietors: in representing the Jew as inferior, they put themselves in the enviable position of people who are superior. Alma's emphasis on Joshua's Jewishness and hatred towards him satisfied her illusion that she belonged to a higher class and therefore construct a better identity other than white trash. However, just like Dmitri's passing and violence, anti-Semitism provides no practical way for Alma to assert her authorship over her own life. Her hatred towards Joshua led her to death rather than self-definition.

\section{Conclusions}

With her unique, masterful writing skill and surprising tenderness, Oates probes the question of identity in contemporary American society and challenges the accepted ideas such as ethnic hatred, class stratification. The three main characters in the novel, with their utterly different backgrounds, exhibit different individuals' identity crisis and their futile attempts to construct new identities from three different perspectives. Oates favors no happy ending in her works and The Tattooed Girl is no exception. At the end of the novel, Joshua fell to his death, Alma was murdered by Jet and Dmitri remained a loser. No one in the book succeeded to get out of their identity crisis, a tinge of determinism prevailing the whole story. Through this tragic ending, Oates repeats her favorite theme that lives are preordained and that one cannot escape one's destiny. However, this novel hardly stands as a monotonous repetition of her previous works. Taking it into account that the novel was published against the backdrop of the post $9 \cdot 11$ era, it is obvious that by portraying the doomed failure of these three characters, Oates reflects a national crisis and expresses her deep concern over the plight of contemporary Americans in her writing.

\section{Acknowledgements}

This paper is part of the result of the research program the author hosts, "Body Study in Joyce Carol Oates's Novels", No. 2015SJB516.

\section{REFERENCES}

[1] Stern, Carol Simpson. "Joyce Carol Oates Biography". Biography, 2002. p. 112, 114.

[2] Hardwick, Lorna \& Porter, James I. "Joyce Carol Oates". In Sibylline Sisters: Virgil's Presence in Contemporary Women's Writing. Fiona Cox. Oxford: Oxford University Press, 2011. p. 209, 210, 215.

[3] Wang, Xiaodan. The Construction of Identities in Joyce Carol Oates's Recent Novels. Shanghai International Studies University, 2013.

[4] Oates, Joyce Carol. The Tattooed Girl. London: Fourth Estate, 2004.p. 49, 259, 49, 119, 138, 67, 23, 35, 62-63, 199, 26-28, 101, 258

[5] Hall, Stuart. "The Question of Cultural Identity". In Modernity: An Introduction to Modern Societies. Ed. Stuart Hall, Oxford: Blackwell Publishing Ltd, 1996, p. 587.

[6] Sartre, Jean-Paul. Being and Nothingness: An Essay on Phenomenological Ontology. Transl. George J Becker. New York: Schocken Books, 1970. p. 69, 27.

[7] Shapiro, Edward S. We Are Many: Reflections on American Jewish History and Identity. New York: Syracuse University Press, 2005. p. xvii.

[8] Dershowitz, Alan. The Vanishing American Jew: In Search of Jewish Identity for the Next Century. New York: Little, Brown and Company, 1997. p. 2.

[9] Waugh, Pataricia. Metafiction: The Theory and Practice of Self-Conscious Fiction. London: Taylor \& Francis e-Library, 2001. p. 21.

[10] Harkins, Anthony. Hillbilly: A Cultural History of an American Icon. New York: Oxford University Press, 2003. p. $5,4$.

[11] Newitz, Annalee. White Trash: Race and Class in America. New York: Routledge, 1997. p. 2.

[12] Isenberg, Nancy. White Trash. London: Atlantic Books, 2016. p. $135,2,2$. 
[13] Hundley, Daniel. "Poor White Trash", in Social Relations in Our Southern States, 1860. p. 250.

[14] Weston, George. The Poor Whites of the South, Washington: Buell and Blanchard, 1856. p. 5.

[15] Wray, Matt. Not Quite White. Durham: Duke University Press, 2006. p. 2.

[16] Hall, Stuart. "Minimal Selves", in Black British Cultural Studies: A Reader. Ed. Houston Baker. Chicago: University of Chicago Press, 1996. p. 117.

[17] Renfrow, Daniel G. "A Cartography of Passing in Everyday Life," Symbolic Interaction, 2004 Vol. 27, Issue 4, p. 485-506.

[18] Ginsberg, Elaine. Passing and the Fictions of Identity. Durham: Duke University Press, 1996. p. 2.
[19] Meuronen, Jutta. "I am not my father, I am scarcely myself." University of Tampere, 2012. p. 32, 34.

[20] Kirubahar, Samuel. "Oatesian World of Violence and Female Victimization-An Autopsy". Language in India, 2011 (1 January), p. 112.

[21] Farry E. "Behind the scenes of The Tattooed Girl". In The Tattooed Girl. Ed. Farry E. London: Harper Perennial, 2004. p. 12.

[22] Dyer, Richard. White: Essays on Race and Culture. London: Routledge, 1997. p. 212.

[23] Blakeslee, Spenser. The Death of American Antisemitism. Library of Congress Cataloging-in-Publication Data, 2000. p. 3. 